\title{
Book Review (Descriptive): Bernard D., Andrew L., Peter A. Ioannis S. (2018). Food and Beverage Management; Fourth Edition
}

\author{
Ayana Fiseha \\ Lecturer and Department Head of Tourism and Hotel Management, Bahir Dar University College of Business \\ and Economics, Bahir Dar, Ethiopia
}

Title of Book: Food and Beverage Management

Authors: Bernard D., Andrew L., Peter A. Ioannis S.

Publisher: Elsevier Butterworth-Heinemann publications, 2008, containing 426 pages

Cover: Paperback or visit website at www.bh.com.

DOI: $10.7176 / \mathrm{JTHS} / 53-04$

Publication date: January $31^{\text {st }} 2021$

This book is a result of academic achievement and longtime practical experience of authors in the food and beverage management, and their exposure to produce the book. Bernard D., Andrew L. who are corresponding authors have used their own practical experiences and first-hand information obtained from practitioners of large and small catering companies and units to undertake research for the book. Moreover, corresponding authors welcomed two new experienced teachers Peter Alcott and Ioannis Pantelidis onto the authorship of fourth edition of this book. Peter Alcott who has followed a long career in teaching and developing new young managers of the future of the hospitality industry has contributed a lot in some major changes of this book. Ioannis Pantelidis who has been following a successful career in the management of restaurants and hotels as well as teaching and consulting has also realized some major changes in this edition.

I am impressed with this book since it is very interesting, has Pedagogical features and presents the subject matter in clear way. Each chapter begins with brief introduction of the topic to the reader. The concepts of the text in the chapters are supported with flow diagrams, tables, screenshots, case studies as well as career insights and tips to enable the discussion. Activities such as concept-review and critical thinking questions and project work are included in the presentation. This enhances the readers' cognitive and real-time application-based learning of food and beverage industry. Tips are involved in each chapter; this helps readers to remember and to recapitulate important concepts of discussion. Case studies are also raised to inspire the readers to analyze real-time problems. References are also included at the end of each chapter for further readings.

In addition, the authors indicated requirements of the various degree courses in hotel and catering administration and management, the hotel and catering institutional management association, and diplomas and certificates of the business and technician education. Authors advocate the book to be used as manual for training and practicing food and beverage managers, food and beverage supervisors, food and beverage controllers, chefs, and all their assistants who may wish to formalize and update their knowledge in order to improve the profitability and productivity of their operations and to enhance customer satisfaction.

From this book, the reader can get intense knowledge about food and beverage management. It explains the complexities of managing food and beverage outlets in five broad sections of the catering industry namely, fastfood and popular catering, hotels and quality restaurants, function catering, industrial catering and welfare caterings. Authors further discussed the details of standard industrial classification explicitly, accommodation and food service activities, holiday and other short-stay accommodation, restaurants and mobile food service activities, licensed restaurants, unlicensed restaurants and cafes, take away food shops and mobile food stands, event catering activities, contract catering, leisure venue catering, travel catering, roads/motor side, trains, cruise ships/ferry boats, vending machines of beverage serving activities.

The authors examined the comprehensive range of subject areas from food and beverage operational management perspective and relate to apply within all sections of the catering industry. They discussed about concept development of food and beverage policy and strategy, feasibility study, organization environment (PESTLE analysis), market analysis, the business plan, financing of the operation as well as facility design and layout.

The book gives a brief description of the food and beverage industry particularly, the objectives and need for food and beverage control, special problems of food and beverage control and factors affecting food and beverage control, fundamentals and reality of food and beverage control, methods of food and beverage control, profit sensitivity and menu engineering. The authors also looked about frauds of food and beverage as major causes for loss of revenue in catering establishments, along with prevention tactics to provide a better understanding to manage an establishment. 
The book provides rich facts about food and beverage menu planning, pricing, menu types, offering and merchandizing, manual and computerized revenue control systems, forecasting and operations ratio of menu, cost and profit analysis, break-even analysis, and variance analysis. It describes various types of budget, steps in preparing budgets, and the importance of budgeting in food and beverage establishments. It provides details about sales control which includes calculating the selling price, points to be considered while fixing the selling price, billing of sales which could be both cash and credit sales, and the reports generated.

It offers vivid knowledge of food and beverage control at various stages of control cycle that comprises purchasing, receiving, storing, issuing producing, preserving, serving, and accounting with emphasis of automated systems, while considering the basic formats and process. Concerning the purchasing, it deals with standard purchase specification, different methods of purchasing, and the various common procedures followed in purchasing food and beverage. It also discourses the receiving function which includes bills and invoices, credit note, various kinds of equipment used in receiving, and the records and reports generated in this section. The book also discusses how to follow food and beverage storing and issuing procedures, and it suggests using of various types of inventories management techniques in catering establishments as per the need. Production control in food and beverage management, which includes costing, preparing standard recipes, standard portion size and cost, yield testing of food, and daily and monthly food costing is also discussed in the book. Related with this, the book discusses cost/volume profit analysis to provide a better understanding of management of an establishment, menu management to assist in planning and costing a menu, and new trends in the industry such as revenue management, strategic management and total quality management.

The book deals with the marketing strategies in food and beverage operations. It underlines advertising, public relations, merchandizing, sales promotion, and personal selling and upselling to be applied in food and beverage operations marketing. It also elaborates how to develop systematic approaches to quality management of food and beverage operations.

The book describes labor issues in catering establishments which incorporates planning, forecasting recruitment, scheduling, supervision and communication of staff. It also discusses staff training, staff turnover and legal framework, labor cost control and payroll analysis of food and beverage staff.

The book advices to consider and update fast moving changes and developments in hospitality industry namely, consumer trends, new visions of technology, health and environmental issues and awareness, financing the operation, ethical issues, consolidation and the growth of brands, customer expectations of products and services and the growth in the value of the industry to the economy at the local, regional and global level.

Generally, the book is collection of each author's academic achievement and practical endeavor. The book relates with latest published book "Food and beverage management" written by Partho Pratim Seal (2017); Oxford University press. There is much to be learned from the book. Authors' Presentation of the book is greatly important to food and beverage managers, food and beverage supervisors, food and beverage controllers, chefs, and their assistants to formalize and update their knowledge, to update and cope with fast moving changes and developments in hospitality industry. In my view, I haven't observed weaknesses and limitations sides from the book. I got it Very important book for me. Really, I used this book to teach certificate, diploma as well as undergraduate programs in hospitality field of study. Currently I also used this book to develop food and beverage management course when I developed Masters of Hospitality Business Administration curriculum at university where I am working. I suggest all of food and beverage professionals to use this book to get intense knowledge for professional and career development. I also suggest academicians and academic institutions of the field to use this book as standard text book or training guide book for certificate and diplomas levels as well as undergraduate and postgraduate programs in hospitality field of studies. 